\title{
PARTICIPATION OF CANNABINOID RECEPTORS IN ANTIPRURITIC ACTIVITY INDUCED BY SYSTEMIC DIPYRONE IN MICE
}

\author{
Erdem Altan ${ }^{1}$ (D), Najaf Ali Folladwand ${ }^{1}$ (D), Rymejsa Gurmani ${ }^{1}$ (D), Ömür Türkü Özşalap ${ }^{1}$ (D) Kübra Duvan Aydemir² (D), \\ Ahmet Ulugöl2 (1)
}

${ }^{1}$ Trakya University School of Medicine, Edirne, TURKEY

${ }^{2}$ Trakya University School of Medicine, Department of Medical Pharmacology, Edirne, TURKEY

\section{ABSTRACT}

Aims: The cannabinoid system has been shown to contribute to the antinociceptive effects of nonsteroidal anti-inflammatory drugs. Considering the similar pathophysiological mechanisms underlying pain and itching, we aimed to observe whether dipyrone has an antipruritic effect and whether cannabinoid receptors are involved in this effect.

Methods: In this project, we produced scratching behavior in BALB/c mice, intradermally administering the well-known pruritic agent compound $48 / 80$. After observing the anti-scratching effect of dipyrone with increasing doses, we administered AM-251 (1 mg/kg, intraperitoneal) and AM-630 (3 mg/kg, intraperitoneal) to determine whether the endocannabinoid system was associated with this effect of dipyrone.

Results: Dipyrone reduced scratching behavior at its highest dose used in this study (600 mg/kg); however, neither AM-251 nor AM-630 changed the antipruritic action of dipyrone.

Conclusion: Our findings indicate that dipyrone, at higher doses, attenuates compound 48/80-induced scratching behavior in mice. Cannabinoid receptors have been found not to be involved in the antipruritic effect of dipyrone. Further experiments are required to delineate the mechanisms underlying this highdose dipyrone effect.

Keywords: AM-251, AM-630, dipyrone, pruritus

\section{INTRODUCTION}

Cannabinoids have been known to reduce pain for centuries; however, several reasons preclude their use as effective analgesics (1). These chemical compounds include synthetic cannabinoids, those found in the Cannabis plant (phytocannabinoids), and those distributed throughout the body (endocannabinoids) (1). All cannabinoids activate cannabinoid receptors (CB1 and $\mathrm{CB} 2$ ) and take place in many pathophysiological processes (1). CB1 receptors are distributed widely in the central nervous system and appear to play the predominant role in both the therapeutic and the central adverse effects of these drugs (1). Despite a great deal of research, cannabinoids are only used in limited indications. Synthetic cannabinoids, dronabinol and nabilone, are used in the treatment of chemotherapy-associated emesis, and nabilone is also approved for anorexia associated with acquired immunodeficiency syndrome (1). Nabiximol ( $\Delta 9$ tetrahydrocannabinol + cannabidiol) is recommended for use in neuropathy and spasticity associated with multiple sclerosis and cancer pain $(2,3)$. These cannabinoids are still alternatives in aforementioned indications and are approved only in some countries; however, numerous ongoing clinical

Address for Correspondence: Erdem Altan, Trakya University School of Medicine, Edirne, TURKEY

e-mail: erdemaltan@trakya.edu.tr

ORCID iDs of the authors: EA: 0000-0002-4026-5447; NAF: 0000-0001-9542-6650; RG: 0000-0002-2013-0297;

ÖTÖ: 0000-0002-9311-4538; KDA: 0000-0001-5573-4915; AU: 0000-0003-4643-1124

Received: 16.11.2021 Accepted: 30.11.2021

Cite this article as: Altan E, Folladwand NA, Gurmani R et al. Participation of cannabinoid receptors in antipruritic activity induced by systemic dipyrone in mice. Turk Med Stud J 2022;9(1):20-4.

Copyright@Author(s) - Available online at https://www.turkmedstudj.com/ 
trials seem to enhance their usage in different pathological conditions in addition to its use for pain reduction $(2,3)$.

Nonsteroidal anti-inflammatory drugs (NSAIDs) are a group of medicines used worldwide to reduce pain, fever, and inflammation (4). They block the cyclooxygenase enzymes (COX-1, COX-2) and inhibit the production of prostaglandins (4). Distinct from traditional NSAIDs, paracetamol and dipyrone appear not to act on peripheral COX enzymes; a recent research indicates that they do not have a direct significant effect on endocannabinoid levels in a rat's brain and spinal cord (4). Yet, there are previous studies indicating that both increases in endocannabinoid tonus and cannabinoid receptors are associated with the antinociceptive effects of paracetamol and dipyrone (5-7). The cannabinoid system has also been proposed to participate in antipyretic, anxiolytic, and anticonvulsive effects of these drugs, although there are contradictory data (7-10).

Pruritus, also known as itching, is an uncomfortable, irritating sensation that provokes the urge to scratch (11). It is the predominant symptom of many diseases and can affect the quality of life (11). Overall, pruritus and pain are two sensations showing many similarities, especially in pathological and chronic conditions (11, 12). Accordingly, similar to pain, involvement of the cannabinoid system in the development of pruritus and the probable therapeutic effect of cannabinoids in pruritic states have been suggested (13, 14). Cannabinoid agonists have been shown to attenuate histamine-induced responses, while rimonabant, CB1 receptor antagonist, induced scratching behavior $(13,14)$. Similarly, we presented that activation of cannabinoid receptors using the synthetic cannabinoid agonist WIN 55,212-2 and enhancing endocannabinoid tonus via blockade of endocannabinoid degrading enzymes, fatty acid amide hydrolase, and monoacylglycerol lipase exhibit dose-dependent antipruritic activity (15-17).

This study aims to examine whether dipyrone reduces itching behavior induced by compound 48/80 (C 48/80) and to observe whether cannabinoid receptors mediate dipyrone's effects in case of any antipruritic action.

\section{MATERIAL AND METHODS}

\section{Animals \& Ethics}

In this study, male BALB/c mice (2-3 months) weighing 20$30 \mathrm{~g}$ were used (Center of the Laboratory Animals, Trakya University). All animals were housed in a light (12/12 h day/ night cycles) and temperature-controlled $\left(21 \pm 2{ }^{\circ} \mathrm{C}\right)$ room where food and water were available ad libitum. A total of 48 mice were used in this study. Separate groups, each involving 6 mice were used for each set of experiments. The experiments were conducted after approval of the local "Animal Care Ethics Committee" (protocol code: TÜHADYEK-2019/27, date: 25.10 .2019$)$. Moreover, during all procedures, the Ethical Committee of the International Association for the Study of Pain guidelines were followed strictly (18).

\section{Study Design}

Itching behavior was evoked by intradermal injection of $100 \mu \mathrm{g} / 50 \mu \mathrm{L}$ of $\mathrm{C} 48 / 80$ into the rostral part of the back of each mouse. Several scratches per second were accepted as one bout of scratching. These scratches were videotaped and counted for 30 minutes, beginning just after administering $C 48 / 80$. To examine the antipruritic effect of the drug, different doses of dipyrone [150, 300, $600 \mathrm{mg} / \mathrm{kg}$, intraperitoneal (i.p.)] were tested. Subsequently, effects of the cannabinoid CB1 receptor antagonist AM-251 1 mg/kg, i.p.) and the cannabinoid $C B 2$ receptor antagonist $A M-630$ ( $3 \mathrm{mg} / \mathrm{kg}$, i.p.) on the antipruritic activity of dipyrone were analyzed. Dipyrone was injected 30 minutes before C 48/80 administration, and cannabinoid receptor antagonists were administered 10 minutes before dipyrone.

\section{Drugs}

Compounds 48/80 and AM-630 were supplied from SigmaAldrich (St Louis, MO, USA); AM-251 was obtained from Tocris (UK); and dipyrone was purchased from Cayman (Ann Arbor, MI, USA). C 48/80 and dipyrone were dissolved in physiological saline, while AM-251 and AM-630 were administered in $20 \%$ dimethyl sulfoxide, $1 \%$ Tween $80,1 \%$ ethanol, and $78 \%$ saline. Doses of each drug and treatment schedules were chosen from our previous studies (19-24).

\section{Statistical Analysis}

Graphpad Prism 8.4 was used for statistical analysis and to plot the graphs. To assess the significance of any difference between groups, the Kruskal-Wallis test, then Dunn's Multiple Comparisons test were performed. In all analyses, $p<0.05$ was considered statistically significant.

\section{RESULTS}

\section{Reduction of Compound 48/80-induced Scratching Behavior by Dipyrone}

Dipyrone $(150,300,600 \mathrm{mg} / \mathrm{kg})$ administration attenuated C 48/80-induced scratches at its highest dose $(30 \mathrm{mg} /$ $\mathrm{kg}$; ${ }^{*} \mathrm{p}<0.001$, compared to vehicle); but treatment with lower dipyrone doses had no effect on scratching behavior (Figure 1).

\section{Influence of Cannabinoid Receptor Antagonism on Dipyrone-induced Antipruritic Activity}

Neither AM-251 (1 mg/kg) nor AM-630 (3 mg/kg) had any influence on the antipruritic activity of dipyrone (Figure 2). 


\section{Effect of Cannabinoid Receptor Antagonists on Compound 48/80-induced Scratching Behavior When Administered Alone}

When administered alone, AM-251 (1 mg/kg) had no effect on $C 48 / 80$-induced scratching activity whereas AM-630 ( $3 \mathrm{mg} / \mathrm{kg}$ ) reduced C 48/80-induced scratches $\left({ }^{*} p<0.001\right.$, compared to the vehicle; Figure 3).

\section{DISCUSSION}

Dipyrone is one of the most extensively used non-opioid analgesic drugs (25). Unlike traditional NSAIDs it has low anti-inflammatory activity but exerts substantial analgesic efficacy (25). It has been suspected for a long time that the central nervous system plays role in the antinociceptive effect of dipyrone and the contribution of the endocannabinoid system is one of the topics attracting attention to explain its mechanism of action (25). In this study, we investigated whether dipyrone produced antipruritic effects in mice who developed scratching behavior following C 48/80

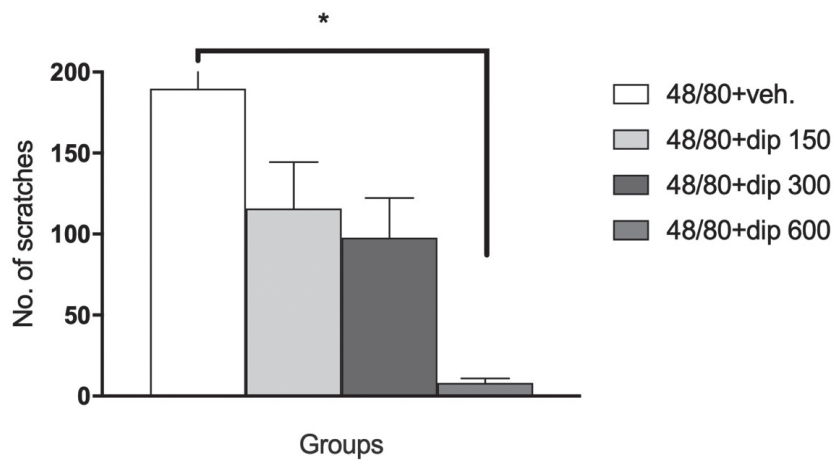

Figure 1: Effects of dipyrone $(150,300,600 \mathrm{mg} / \mathrm{kg}$, i.p.) on compound $48 / 80$-induced scratches ( ${ }^{*} \mathrm{p}<0.001$, compared to vehicle).

veh.: Vehicle, dip: Dipyrone

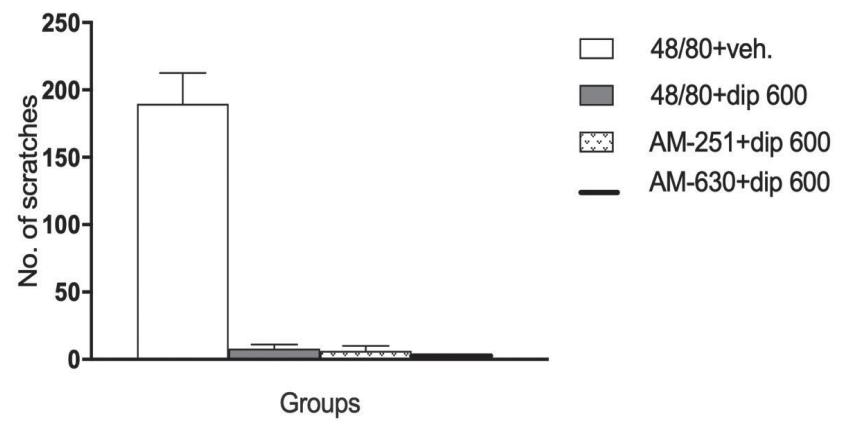

Figure 2: Effects of the cannabinoid CB1 receptor antagonist AM-251 (1 $\mathrm{mg} / \mathrm{kg}$, i.p.) and the cannabinoid CB2 receptor antagonist AM-630 (3 $\mathrm{mg} / \mathrm{kg}$, i.p.) on the antipruritic activity of dipyrone $(600 \mathrm{mg} / \mathrm{kg}$, i.p.). veh.: Vehicle, dip: Dipyrone administration and observed the contribution of cannabinoid receptors to its antipruritic action. In this study, dipyrone was found to be alleviating scratching at higher doses, but blockade of cannabinoid receptors was not found to be changing this effect.

There are studies indicating that cannabinoid agonists and drugs elevating endocannabinoid tonus locally exert antipruritic effects (13-17). However, only a very limited number of studies have been conducted on the effects of NSAIDs, the non-opioid analgesic dipyrone and paracetamol, on pruritus. Systemic administration of two classical NSAIDs, tenoxicam and diclofenac, significantly reduced the incidence and severity of postoperative pruritus in patients receiving epidural opioids $(26,27)$. Moreover, paracetamol has been shown to reduce scratching behavior, especially at higher doses, but antagonism of CB1 and CB2 receptors have been shown not to prevent the antipruritic effects of systemic paracetamol (28-30). Similar to observations on paracetamol studies, our results indicate that dipyrone elicited antipruritic effects at the highest dose. Since many analgesic drugs dose-dependently blocked serotonin and C 48/80-induced scratching behaviors, with some exhibiting complete inhibition at certain doses, further experiments are needed to discriminate whether our findings will be evaluated as falsepositive responses or not (29).

In this study, to clarify the mechanism of systemic dipyrone's antipruritic effect, the cannabinoid receptors were antagonized with AM-251 and AM-630. We observed that cannabinoid receptor antagonists had no influence on the anti-scratching effect of dipyrone, signaling that mechanisms other than the cannabinoid receptors are mediating its antipruritic action. In addition to COX inhibition, the classical mechanism of NSAIDs' effects such as the release of endogenous opioids, participation of nociceptin/orphanin FQ receptors, L-arginine/ $\mathrm{NO} / \mathrm{CGMP} / \mathrm{K}_{\text {ATP }}$, and/or the glutamatergic systems are among the suggested mechanisms for the peripheral and central

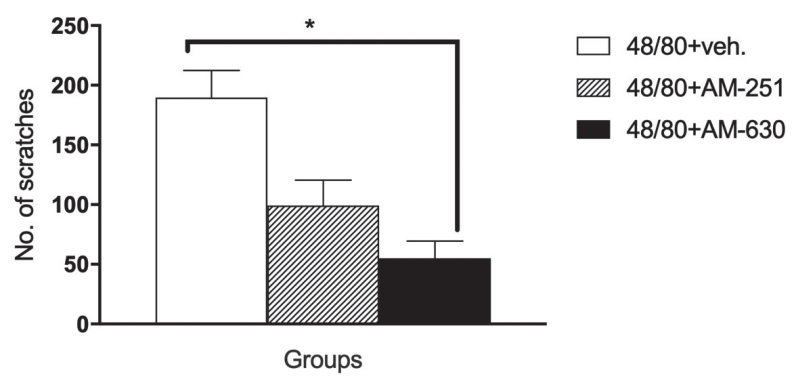

Figure 3: Effects of the cannabinoid CB1 receptor antagonist AM-251 (1 $\mathrm{mg} / \mathrm{kg}$, i.p.) and the cannabinoid CB2 receptor antagonist AM-630 (3 $\mathrm{mg} / \mathrm{kg}$, i.p.) on compound $48 / 80$-induced scratches when administered alone $\left({ }^{*} \mathrm{p}<0.001\right.$, compared to the vehicle).

veh.: Vehicle, dip: Dipyrone 
antinociceptive effects of dipyrone (21, 31-35). Similar to its antinociceptive activity, all of these mechanisms may also mediate the antipruritic action of dipyrone, but detailed experiments on this area should be conducted.

Another interesting finding of our study was that the CB2 receptor antagonist AM-630 had no effect on the antipruritic effect of dipyrone but unexpectedly exerted anti-scratching properties when administered alone. Since CB2 receptors are mainly expressed in the periphery and do not mediate the central effects of cannabinoids, this appears to be an exceptional result. In our earlier studies, we found that AM630 , when injected intrathecally, did not exert any effect on its own or altered the antinociceptive action of diclofenac $(36,37)$. When other pruritus models, different techniques, and/or different routes of administration are used, we hope to see similar results as AM-630 having no effect when administered alone.

\section{CONCLUSION}

We observed that the non-opioid analgesic drug dipyrone reduces $C$ 48/80-induced scratching behavior in mice when given systemically, but only when it is used at the highest dose. Blockade of cannabinoid receptors has not participated in this antipruritic activity of high-dose dipyrone.

Ethics Committee Approval: This work was approved by Trakya University Local Ethics Committee of Animal Experiments (protocol code: TÜHADYEK-2019/27, date: 25.10.2019).

\section{Informed Consent: N/A}

Conflict of Interest: The authors declared no conflict of interest.

Author Contributions: Concept: K.D.A., A.U., Design: E.A., N.A.F., R.G., Ö.T.Ö., K.D.A., A.U., Supervision: K.D.A., A.U., Resources: K.D.A., A.U., Materials: E.A., N.A.F., R.G., Ö.T.Ö., K.D.A., A.U., Data Collection and/or Processing: E.A., N.A.F., R.G., Ö.T.Ö., K.D.A., A.U., Analysis and/or Interpretation: E.A., N.A.F., R.G., Ö.T.Ö., K.D.A., A.U., Literature Search: E.A., N.A.F., R.G., Ö.T.Ö., K.D.A., A.U., Writing Manuscript: K.D.A, A.U., Critical Review: E.A., N.A.F., R.G., Ö.T.Ö., K.D.A., A.U.

Financial Disclosure: This work was supported by a grant from Trakya University Research Council (TÜBAP-2019/266).

\section{REFERENCES}

1. Ulugöl A. The endocannabinoid system as a potential therapeutic target for pain modulation. Balkan Med J 2014;31:115-20. [Crossref]

2. Sastre-Garriga J, Vila C, Clissold S et al. THC and CBD oromucosal spray (Sative ${ }^{\circledR}$ ) in the management of spasticity associated with multiple sclerosis. Expert Rev Neurother 2011;11:627-37. [Crossref]
3. Schrot RJ, Hubbard JR. Cannabinoids: Medical implications. Ann Med 2016;48:128-41. [Crossref]

4. Topuz RD, Gunduz $\mathrm{O}$, Karadag $\mathrm{CH}$ et al. Endocannabinoid and $\mathrm{N}$-acylethanolamide levels in rat brain and spinal cord following systemic dipyrone and paracetamol administration. Can J Physiol Pharmacol 2019;97:1035-41. [Crossref]

5. Mallet C, Daulhac L, Bonnefont J et al. Endocannabinoid and serotonergic systems are needed for acetaminophen-induced analgesia Pain 2008;139:190-200. [Crossref]

6. Rogosch T, Sinning C, Podlewski A et al. Novel bioactive metabolites of dipyrone (metamizol). Bioorg Med Chem 2012;20:101-7. [Crossref]

7. Crunfli F, Vilela FC, Giusti-Paiva A. Cannabinoid CB1 receptors mediate the effects of dipyrone. Clin Exp Pharmacol Physiol 2015;42:246-55. [Crossref]

8. Topuz RD, Gündüz O, Dökmeci $D$ et al. Does dipyrone produce anxiolyticlike effects in mice? Cukurova Med J 2019;44:866-74. [Crossref]

9. Schlosburg JE, Radanova L, Di Marzo V et al. Evaluation of the endogenous cannabinoid system in mediating the behavioral effects of dipyrone (metamizol) in mice. Behav Pharmacol 2012;23:722-6. [Crossref]

10. Umathe SN, Manna SS, Utturwar KS et al. Endocannabinoids mediate anxiolytic-like effect of acetaminophen via CB1 receptors. Prog Neuropsychopharmacol Biol Psychiatry 2009;33:1191-9. [Crossref]

11. Davidson S, Giesler GJ. The multiple pathways for itch and their interactions with pain. Trends Neurosci 2010;33:550-8. [Crossref]

12. Ross SE. Pain and itch: insights into the neural circuits of aversive somatosensation in health and disease. Curr Opin Neurobiol 2011;21:880-7. [Crossref]

13. Dvorak M, Watkinson A, McGlone F et al. Histamine induced responses are attenuated by a cannabinoid receptor agonist in human skin. Inflamm Res 2003;52:238-45. [Crossref]

14. Schlosburg JE, O'Neal ST, Conrad DH et al. CB1 receptors mediate rimonabant-induced pruritic responses in mice: investigation of locus of action. Psychopharmacology (Berl) 2011;216:323-31. [Crossref]

15. Bilir KA, Anli G, Ozkan E et al. Involvement of spinal cannabinoid receptors in the antipruritic effects of WIN 55,212-2, a cannabinoid receptor agonist. Clin Exp Dermatol 2018;43:553-8. [Crossref]

16. Todurga ZG, Gunduz $\mathrm{O}$, Karadag $\mathrm{CH}$ et al. Descending serotonergic and noradrenergic systems do not regulate the antipruritic effects of cannabinoids. Acta Neuropsychiatr 2016;28:321-6. [Crossref]

17. Tosun NC, Gunduz O, Ulugol A. Attenuation of serotonin-induced itch responses by inhibition of endocannabinoid degradative enzymes, fatty acid amide hydrolase and monoacylglycerol lipase. J Neural Transm (Vienna) 2015;122:363-7. [Crossref]

18. Zimmermann M. Ethical guidelines for investigations of experimental pain in conscious animals. Pain 1983;16:109-110. [Crossref]

19. Yilmaz I, Ulugol A. The effect of nitric oxide synthase inhibitors on the development of analgesic tolerance to dipyrone in mice. Int J Neurosci 2009;119:755-64. [Crossref]

20. Elmas P, Ulugol A. Involvement of cannabinoid CB1 receptors in the antinociceptive effect of dipyrone. I Neural Transm (Vienna) 2013;120:1533-8. [Crossref]

21. Ertin IH, Gunduz O, Ulugol A. Contribution of nociceptin/orphanin FQ receptors to the anti-nociceptive and hypothermic effects of dipyrone. Acta Neuropsychiatr 2015;27:48-52. [Crossref]

22. Gencer A, Gunduz O, Ulugol A. Involvement of Descending Serotonergic and Noradrenergic Systems and their Spinal Receptor Subtypes in the Antinociceptive Effect of Dipyrone. Drug Res (Stuttg) 2015;65:645-9. [Crossref] 
23. Aydemir KD, Gunduz O, Ulugol A. Effects of a nociceptin receptor antagonist on experimentally induced scratching behavior in mice. Neurophysiology 2017;49:130-4. [Crossref]

24. Gercek OZ, Oflaz B, Oguz N et al. Role of Nitric Oxide in the Antipruritic Effect of WIN 55,212-2, a Cannabinoid Agonist. Basic Clin Neurosci 2020;11:473-80. [Crossref]

25. Topuz RD, Gündüz Ö, Karadağ ÇH et al. Non-opioid Analgesics and the Endocannabinoid System. Balkan Med J 2020;37:309-15. [Crossref]

26. Colbert S, O'Hanlon DM, Chambers F et al. The effect of intravenous tenoxicam on pruritus in patients receiving epidural fentanyl. Anaesthesia 1999;54:76-80. [Crossref]

27. Colbert S, O'Hanlon DM, Galvin $S$ et al. The effect of rectal diclofenac on pruritus in patients receiving intrathecal morphine. Anaesthesia 1999;54:948-52.[Crossref]

28. Dogrul A, Ilkaya F, Seyrek $M$ et al. The evaluation of antipruritic effect of paracetamol and its metabolite AM404 in an acute allergenic mice model. In. 6th European Congress of Pharmacology: Granada, SPAIN. 2012. [Crossref]

29. Ilkaya F, Yesilyurt $O$, Seyrek $M$ et al. The false-positive responses of analgesic drugs to the intradermal serotonin- and compound $48 / 80$-induced scratches as an animal model of itch. Acta Neurobiol Exp (Wars) 2016;76:234-43. [Crossref]

30. Saglam G, Gunduz O, Ulugol A. Blockade of cannabinoid CB1 and CB2 receptors does not prevent the antipruritic effect of systemic paracetamol. Acta Neurol Belg 2014;114:307-9. [Crossref]
31. Alves $D$, Duarte I. Involvement of ATP-sensitive $K(+)$ channels in the peripheral antinociceptive effect induced by dipyrone. Eur J Pharmacol 2002;444:47-52. [Crossref]

32. Beirith A, Santos AR, Rodrigues AL et al. Spinal and supraspinal antinociceptive action of dipyrone in formalin, capsaicin and glutamate tests. Study of the mechanism of action. Eur J Pharmacol 1998;345:23345. [Crossref]

33. Campos C, de Gregorio R, García-Nieto R et al. Regulation of cyclooxygenase activity by metamizol. Eur J Pharmacol 1999;378:33947. [Crossref]

34. Siebel JS, Beirith A, Calixto JB. Evidence for the involvement of metabotropic glutamatergic, neurokinin 1 receptor pathways and protein kinase $\mathrm{C}$ in the antinociceptive effect of dipyrone in mice. Brain Res 2004;1003:61-7. [Crossref]

35. Vanegas H, Vazquez E, Tortorici V. NSAIDs, Opioids, Cannabinoids and the Control of Pain by the Central Nervous System. Pharmaceuticals (Basel) 2010;3:1335-47. [Crossref]

36. Chatzisali B, Gas T, Kilgin $\mathrm{H}$ et al. Cannabinoid receptors are not involved in antinociception induced by systemic diclofenac in mice. Turkish Med Stud J 2020;7:1-4. [Crossref]

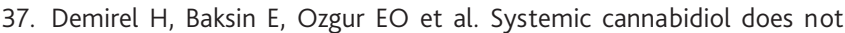
reduce compound 48/80-induced itching behavior in mice. Turkish Med Stud J 2019;6:12-7. [Crossref] 